\title{
HUBUNGAN VARIABILITAS PARAMETER KEAMANAN DAN KENYAMANAN KERJA ABK DAN HASIL TANGKAPAN IKAN PADA PUKAT CINCIN YANG BEROPERASI DI SELAT BALI
}

\author{
THE RELATIONSHIP BETWEEN THE VARIABILITY OF WORK SAFETY AND COMFORT \\ PARAMETERS OF PURSE SEINE CREWS OPERATING ON BALI STRAIT AND ITS CATCH
}

\author{
Suryanto $^{1)}$, Ignatius Tri Hargiyatno ${ }^{1)}$ dan Wingking Era Rintaka Siwi ${ }^{2)}$ \\ 1) Pusat Penelitian Pengelolaan Perikanan dan Konservasi Sumberdaya Ikan \\ Gedung Badan Penelitian dan Pengembangan Kelautan dan Perikananan II, Jl. Pasir Putih 2, Ancol Timur, Jakarta. \\ Telepon : 021.64700928,. Fax. 02164700929 \\ 2) Balai Penelitian dan Observasi Laut, Perancak, Bali \\ Email : yannakristianto@yahoo.com
}

Diterima tanggal: 24 Desember 2012, diterima setelah perbaikan: 29 Maret 2013, disetujui tanggal : 22 April 2013

\begin{abstract}
ABSTRAK
Studi untuk melihat variabilitas tingkat keamanan dan kenyamanan awak kapal pukat cincin dalam usaha untuk mendapatkan tangkapan lemuru di Selat Bali dilakukan dengan mengkaji hubungan variabilitas indek operabilitas anak buah kapal terhadap hasil tangkapan ikan telah dilakukan. Studi menggunakan parameter motion sickness incidence (MSI) dengan kriteria ISO 2631-1, data gelombang rata-rata bulanan Selat Bali Tahun 2008-2009, Indek Musim Ikan, hasil tangkapan lemuru dan jumlah kapal berlabuh di Pelabuhan Muncar Tahun 2008-2009. Hasil menunjukan bahwa nelayan bekerja dalam kondisi keamanan dan kenyamanan kerja sesuai dengan kriteria ISO 2631-1 dan keamanan kerja penarik jaring diindikasikan menjadi pertimbangan utama didalam memutuskan kapal berangkat melaut.
\end{abstract}

Kata kunci : Pukat-Cincin, Motion Sickness, Gelombang, Hasil-Tangkapan

\begin{abstract}
A study to assesses the variability of work safety and comfort levels of fishermen on board of purseiner operating on Bali Strait, in retated to the catch, has been accomplished. To do so, the study assessed the correlation among operability indices based on motion sickness incidence (MSI) with ISO 2631-1 criteria, fishing season indices and catch per unit effort (CPUE) has been done. The result shows that working safety and comfort levels of fishermen on board are conform to ISO 2631-1; further the study also shows that working safety and comfort of fishermen hauling the nets could be an indicator for the boats to take any voyages.
\end{abstract}

Keywords : Purseiner, Motion Sickness, Waves, Catches

\section{PENDAHULUAN}

Selat Bali merupakan pusat perikanan spesies tunggal yaitu lemuru (Sardinella lemuru Bleeker, 1853) dengan area yang relatif sempit (Merta et al. 2000; Prasetyo dan Natsir. 2011). Sardinella lemuru Bleeker merupakan $(80-98) \%$ hasil tangkapan dari perikanan pelagis kecil di Selat Bali (Wudianto. 2011). Terlihat pada Gambar 1, wilayah penangkapan sardinella lemuru berada hampir diseluruh Selat Bali. Penangkapan ikan dilakukan oleh nelayan yang berasal dari Propinsi
Jawa Timur dan Bali. Sejak tahun 1992, pengelolaan sardinella lemuru di Selat Bali didasarkan pada Surat Keputusan Bersama (SKB) antara Gubernur Jawa Timur dan Bali No. 238/1992-647/1992; dimana SKB tersebut mengatur pembatasan jumlah armada pukat cincin dari masing-masing Propinsi (Wiyono. 2011). Eksploitasi sumberdaya perikanan lemuru di Selat Bali secara intensif dimulai sejak dekade 70-an dengan telah berkembangnya alat tangkap purse seine yang mempunyai produktivitas lebih tinggi dibandingkan dengan alat tangkap yang sudah ada 
sebelumnya (Dinas KP Jawa Timur. 2000). Menurut Keputusan Menteri Kelautan dan Perikanan KEP No. 45/MEN/2011 kondisi sumberdaya lemuru sudah mengalami over exploited. Namun, pengelolaan lemuru harus tetap dilanjutkan karena melibatkan sebagian besar nelayan di Selat Bali terutama di Kab Muncar (Jawa Timur) dan Kab. Jimbaran (Bali) (Merta et al., 2000).

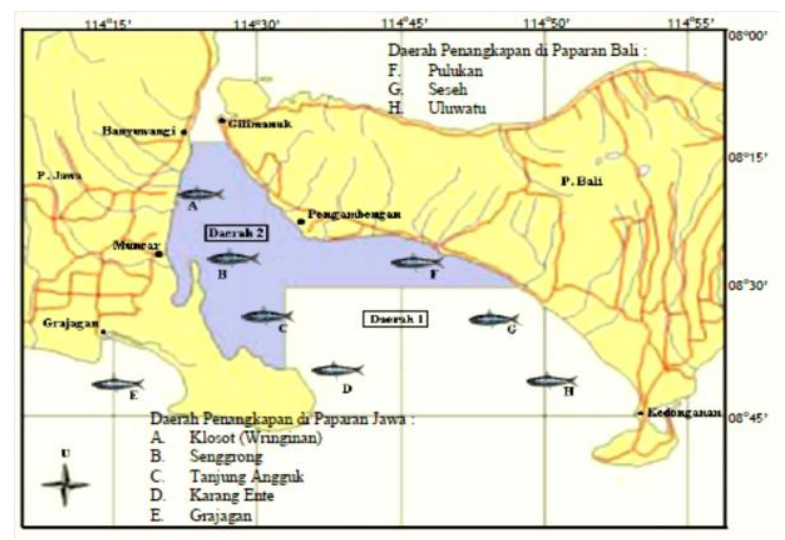

Gambar 1. Daerah Penangkapan Ikan di Selat Bali (Wiyono. 2011).

Fishing Ground of Bali Starit (Wiyono. 2011)

Jumlah nelayan di dunia diperkirakan 30 juta orang yang bekerja diatas 4 juta kapal, dimana 1,3 juta kapal diantaranya memiliki geladak dan 2,7 juta kapal tidak memiliki geladak. 98\% dari kapalkapal tersebut memiliki panjang kurang 24 meter (FAO. 2010). ILO dalam FAO (2010) memperkirakan jumlah kematian pada sektor perikanan tangkap secara global pada tahun 1999 adalah 24.000 orang. Angka tersebut dipercaya lebih besar karena di negara-negara sedang berkembang pencatatan kecelakaan tersebut tidak sempurna (Wang et al. 2005), mendapatkan sebagian besar kecelakaan kapal ikan dilaut terjadi pada kapal dengan panjang seluruh lebih kecil dari 24 meter. Kecelakaan tersebut terutama diakibatkan oleh kerusakan mesin, tenggelam, bocor dan kandas; masing-masing dengan prosentase kejadian sebesar $65.97 \%, 15.41 \%$, dan 8.38\% (Lincoln dan Lucas. 2009) dalam studinya terhadap industri penangkapan ikan di Amerika menyatakan bahwa 52\% kecelakaan laut berupa kerusakan kapal, $31 \%$ berupa anak buah kapal (ABK) yang terjatuh kelaut dan sisanya berupa kecelakaan diatas kapal. Penyebab utama ABK terjatuh kelaut diantaranya adalah karena terpeleset (28\%) dan kehilangan keseimbangan badan (22\%).
Jenis kecelakaan tersebut disebabkan oleh gerakan kapal, kondisi cuaca, geladak yang licin dan kelelahan ABK.

Wiyono (2011) menyebutkan 57\% kapal pukat cincin yang beroperasi di Selat Bali memilili tonase antara (10-30) GT dengan jumlah total nelayan 59.276 orang pada Tahun 2007 dan naik menjadi 64.518 orang pada Tahun 2009. Studi yang lain menunjukan bahwa kapal pukat cincin yang berlabuh di Pengambengan dengan tonase (10-30) GT memiliki panjang (14-21) meter (Suryanto. 2012).

Berdasarkan hasil studi stabilitas kapal pukat cincin Selat Bali pada perairan tenang, didapatkan bahwa, berdasarkan kriteria stabilitas yang ditetapkan oleh FAO/ILO/IMO. (FAO. 2005), kapal memiliki stabilitas statis yang layak pada berbagai kondisi pemuatan kapal. Namun berdasarkan kriteria yang sama, kapal tidak memenuhi satu pun kriteria stabilitas dinamis (Suryanto et al. 2005).

Tupper (1985) dalam studinya di New England Groundfish Industry, mendapatkan adanya hubungan yang erat antara kondisi laut, jumlah trip dan hasil tangkapan sepanjang tahun. Dalam studinya didapatkan 3 parameter utama yang sangat mempengaruhi variasi jumlah tangkapan adalah (1) Efektifitas alat tangkap, (2) Olah gerak kapal terhadap alat tangkap, (3) Pengaruh gerak kapal terhadap kinerja ABK. Sementara Yaakob dan Chau (2005) dalam studinya menunjukan adanya hubungan antara variasi tinggi gelombang dan hasil tangkapan ikan di Semenanjung Barat dan Timur Malaysia.

Berdasarkan informasi tersebut diatas; terlihat bahwa armada pukat cincin Selat Bali termasuk dalam katagori kapal yang memiliki resiko tinggi mengalami kecelakaan dan melibatkan 64.500 nelayan. Sementara sumberdaya lemuru dalam kondisi over exploited, industri pengolahan ikan mengharapkan hasil tangkapan lemuru selalu berkesinambungan. Maka studi untuk melihat tingkat keamanan dan kenyamanan ABK dalam penangkapan ikan dengan menggunakan kapal pukat cincin perlu dilakukan. Keamanan dan kenyamanan kerja diatas kapal terkait secara langsung dengan gerak kapal, maka pendekatan yang dilakukan adalah mengkaji hubungan variabilitas parameter keamanan dan kenyamanan yang dialami oleh ABK dengan hasil tangkapan. 


\section{BAHAN DAN METODE}

Dalam studi ini, obyek yang digunakan adalah kapal pukat cincin pemburu yang beroperasi di Selat Bali yang memiliki ukuran panjang seluruh 21,71 meter, panjang garis air 18,67 meter, lebar 4,75 meter, tinggi geladak 2 meter dan sarat air 1,37 meter dengan rencana garis dan rencana umum disajikan pada Gambar 2 dan 3 dibawah ini.

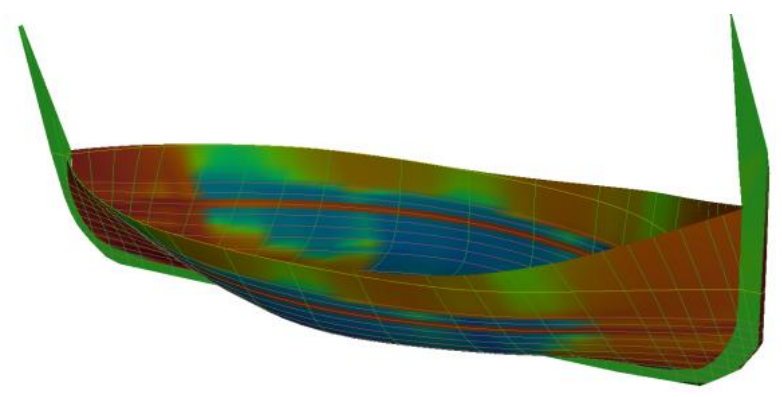

Gambar 2. Rencana Garis Kapal Pukat Cincin Selat Bali (Lines Plan of Bali Strait Purseiner)

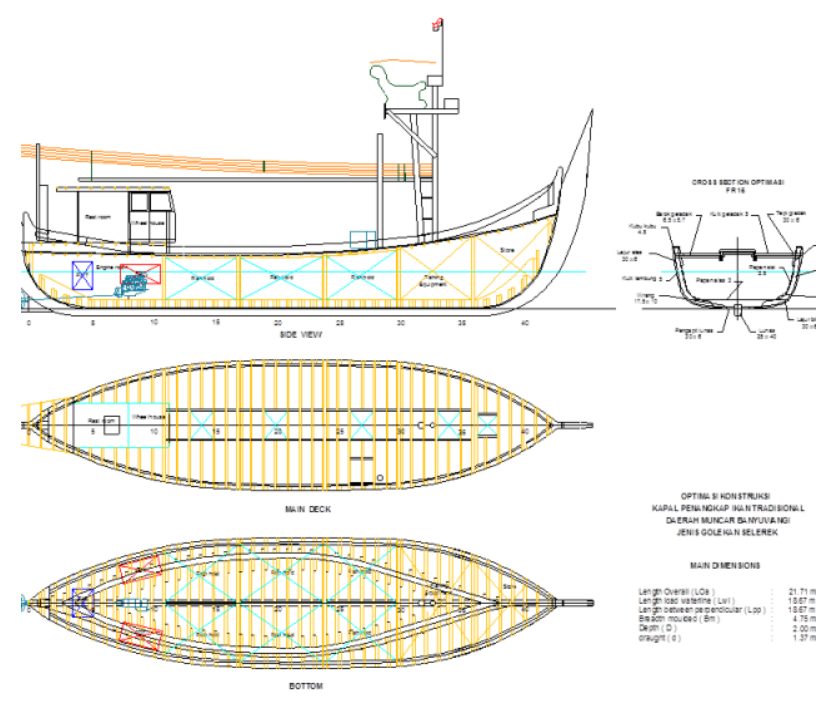

Gambar 3. Rencana Umum dan Konstruksi Pukat Cincin Selat Bali

(General Arrangement and Hull Construction of Bali Strait Purseiner)

Sedangkan sebagai gaya luar yang menyebabkan kapal bergerak adalah gelombang laut Selat Bali tahun 2008-2009 yang dihasilkan oleh Balai Penelitian Observasi Laut (BPOL) Perancak, Bali seperti terlihat pada Tabel 1 .
Tabel 1. Tinggi Siknifikan dan Periode Zero Crossing Gelombang Bulanan Selat Bali Tahun 20082009.

(Monthly Significant Heights and Zero Crossing Periods of Bali Strait Wave of 20082009)

\begin{tabular}{clcc}
\hline NO & BULAN & $\begin{array}{c}\text { Tz } \\
\text { (detik) }\end{array}$ & $\begin{array}{c}\text { Hsig } \\
\text { (meter) }\end{array}$ \\
\hline 1 & Januari & 3,41 & 0,52 \\
2 & Pebuari & 4,35 & 1,08 \\
3 & Maret & 6,64 & 2,04 \\
4 & April & 5,21 & 1,06 \\
5 & Mei & 5,63 & 1,34 \\
6 & Juni & 5,36 & 1,15 \\
7 & Juli & 6,09 & 1,69 \\
8 & Agustus & 3,35 & 0,41 \\
9 & September & 3,61 & 0,47 \\
10 & Oktober & 3,15 & 0,36 \\
11 & Nopember & 5,39 & 1,09 \\
12 & Desember & 3,80 & 0,72 \\
\hline Sumber: Balai Penelitian Perikanan Laut (BPOL)
\end{tabular}

Hasil tangkapan yang digunakan adalah Indek Musim Ikan (MI) yang merupakan rata-rata tangkapan bulanan dari data tangkapan Tahun 1993-2002. Dimana MI kurang dari 1 didefinisikan bukan musim ikan (Merta dan Nurhakim. 2004). Untuk mendapatkan data gelombang dan hasil tangkapan dalam kurun waktu yang sama, studi juga menggunakan data catch per unit effort (CPUE) lemuru rata-rata Tahun 2008 dan 2009 dari Pelabuhan Muncar (Prasetyo dan Natsir. 2011). Dalam analisa, data CPUE yang diperoleh distandarisasikan untuk mendapatkan besaran yang mendekati indek musim ikan dan indek operabilitas ABK.

Dalam studi ini, indek operabilitas ABK diadopsi dari indek operabilitas kapal. Indek operabilitas anak buah kapal adalah persentase waktu dimana berdasarkan kriteria yang digunakan, anak buah dinyatakan aman/ nyaman beroperasi pada suatu kondisi laut tertentu (Grigoropoulosa. 2010).

Indek musim ikan dan standard CPUE lemuru bulanan dimaksud disajikan pada Gambar 4. 


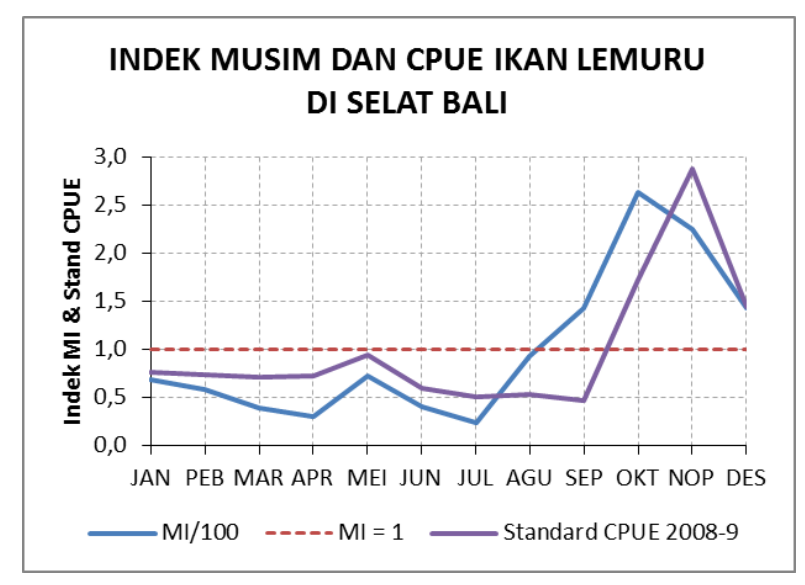

Gambar 4. Musim Ikan Lemuru (MI) di Selat Bali (Fishing Season of Lemuru on Bali Strait)

Simulasi gerak kapal dilaksanakan dengan menggunaka perangkat lunak Seakeeper. Hubungan antara gaya luar yang diakibatkan oleh gelombang dan gerak kapal dicerminkan didalam persamaan defensial linier sebagai;

$$
\begin{aligned}
& \sum_{j=1}^{6}\left\{\left(M_{k j}+A_{k j}\right) \ddot{\xi}_{j}+B_{k j} \dot{\xi}_{j}+C_{k j} \xi_{j}\right\}=F_{k} \mathrm{e}^{\mathrm{i} \omega_{\mathrm{e}} t} \\
& \mathrm{k}, \mathrm{j}=1, \ldots, 6
\end{aligned}
$$

Dimana :

- F k : Amplituda Gaya gelombang komponen ke $\mathrm{k}$

- $\xi_{j}:$ Komponen simpangan gerak kapal ke j (1..6)

- $\dot{\xi}_{j}:$ Komponen kecepatan gerak kapal ke j

- $\ddot{\xi}_{j}:$ Komponen percepatan gerak kapal ke j

- $\quad M_{k j} \quad$ : Matrik massa kapal

- $A_{k j} \quad$ : Matrik koefisien added mass

- $\quad B_{k j} \quad$ : Matrik koefisien damping

- $C_{k j} \quad$ : Matrik koefisien hydrostatic restoring

- $\quad k, j \quad$ : Komponen gaya gelombang dan gerak kapal

Sedangkan nilai koefisien added mass, damping dan hydrostatic restoring diperoleh dengan metode Lewis. Selanjutnya gerak kapal sebagai respon dari gelombang irregular dianalisa dengan menggunakan analisa spekturm linier seperti disarankan oleh Dennis dan Pierson (1953).

Berdasarkan data gelombang bulanan yang diperoleh, gelombang acak disimulasikan dengan menggunakan spektrum gelombang ITTC 2 parameters sebagai;

$$
S_{\zeta}(\omega)=\frac{A}{\omega^{5}} \exp \left(\frac{-B}{\omega^{4}}\right)
$$

Dimana :

$$
\begin{aligned}
-\quad A & =172,75 \frac{H_{\text {sig }}^{2}}{T^{4}} \\
-\quad B & =\frac{691}{T^{4}} \\
-\quad T & =1,087 \mathrm{Tz} .
\end{aligned}
$$

Berdasarkan formula tersebut maka spektrum gelombang bulanan Selat Bali terlihat seperti pada Gambar. 5.

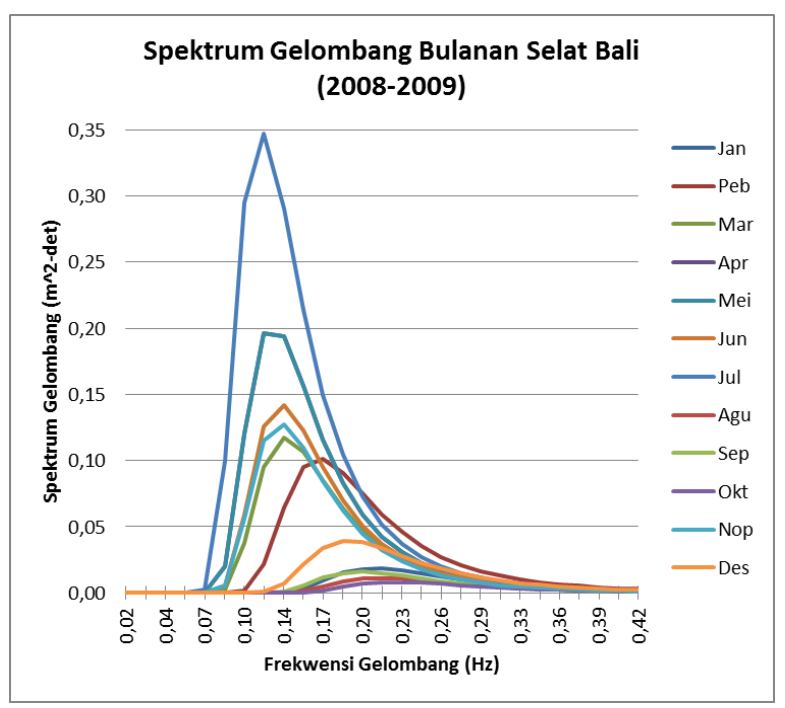

Gambar 5. Spektrum Gelombang Bulanan Selat Bali (Monthly Wave Spectra of Bali Strait)

Variasi arah gelombang relatif terhadap kapal diasumsikan mempunyai probabilitas kejadian yang sama. Karena bentuk kapal simetri, maka arah gelombang relatif terhadap kapal yang digunakan dalam studi ini adalah Buritan $\left(0^{\circ}\right)$, Kwartal Buritan $\left(45^{\circ}\right)$, Lambung $\left(90^{\circ}\right)$, Kwartal Haluan $\left(135^{\circ}\right)$ dan Haluan $\left(180^{\circ}\right)$. Sedangkan kecepatan kapal pukat cincin yang disimulasikan adalah (1-8) knot. Kondisi pemuatan kapal dipilih dimana kapal memiliki stabilitas terburuk yaitu ruang muat ikan dalam keadaan kosong/ berangkat menuju fishing ground (Suryanto et al. 2005). 
Posisi diatas kapal yang ditinjau adalah posisi juru mesin, juru mudi, juragan panggung, tempat ABK beristirahat dan tempat penarik jaring. Posisi tersebut dapat dilihat pada Gambar 6.

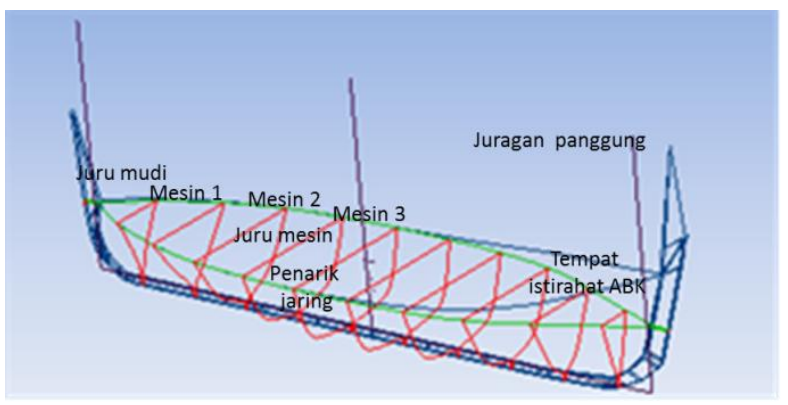

Gambar 6. Posisi ABK diatas kapal yang ditinjau. (Crew On Board Locations under study)

Untuk menghitung parameter yang berhubungan dengan kenyamanan/ keamanan kerja ABK, parameter yang dipakai dalam studi ini adalah Motion Sickness Incidence (MSI) yang dihitung sebagai

$$
\operatorname{MSI}\left(\omega_{\text {e centre }}\right)=\int_{\omega_{e 1}}^{\omega_{e 2}} S_{v . a c c}\left(\omega_{e}\right) d \omega_{e}
$$

Dimana

- $\omega_{e_{1}}$ dan $\omega_{e_{2}}$ adalah batasan frekwensi atas dan bawah dengan $\omega_{e}$ centre sebagai pusat $1 / 3$ oktaf

- $S_{\text {v.acc }}$ adalah spektrum percepatan vertikal absolut dari posisi yang ditinjau.

Nilai kriteria $M S I$ yang dipakai didasarkan pada ISO 2631-1 dengan 10\% ABK mengalami muntah setelah 8 jam pelayaran. Nilai $M S I$ yang ditinjau adalah pada frekwensi $0,169 \mathrm{~Hz}$ dimana pada frekwensi tersebut kondisi motion sickness adalah maksimum terjadi (Griffin. 1990).

Daerah operasional ABK dapat digambarkan dengan menggunakan diagram radar kecepatan (speed polar plot) dengan jari-jari sebesar 1 hingga 8 knot dengan interval 1 knot dan arah gelombang dari $0^{\circ}$ hingga $360^{\circ}$ dengan interval sebesar $45^{\circ}$. Pada setiap variasi kecepatan kapal dan arah gelombang serta spektrum gelombang bulanan yang terjadi, dihitung parameter MSI dari setiap posisi ABK yang ditinjau. Daerah operasional bulanan ABK yang diijinkan adalah luasan diagram radar kecepatan dimana pada variasi kecepatan kapal dan arah gelombang, parameter MSI untuk setiap posisi ABK yang terjadi tidak melebihi batasan kriteria ISO 2631-1. Selanjutnya dihitung indek operabilitas bulanan ABK sebagai perbandingan antara luas daerah operasional bulanan ABK yang diijinkan terhadap luasan seluruh diagram radar kecepatan (Grigoropoulosa. 2010). Contoh diagram radar kecepatan yang dihasilkan disajikan pada Gambar 7.
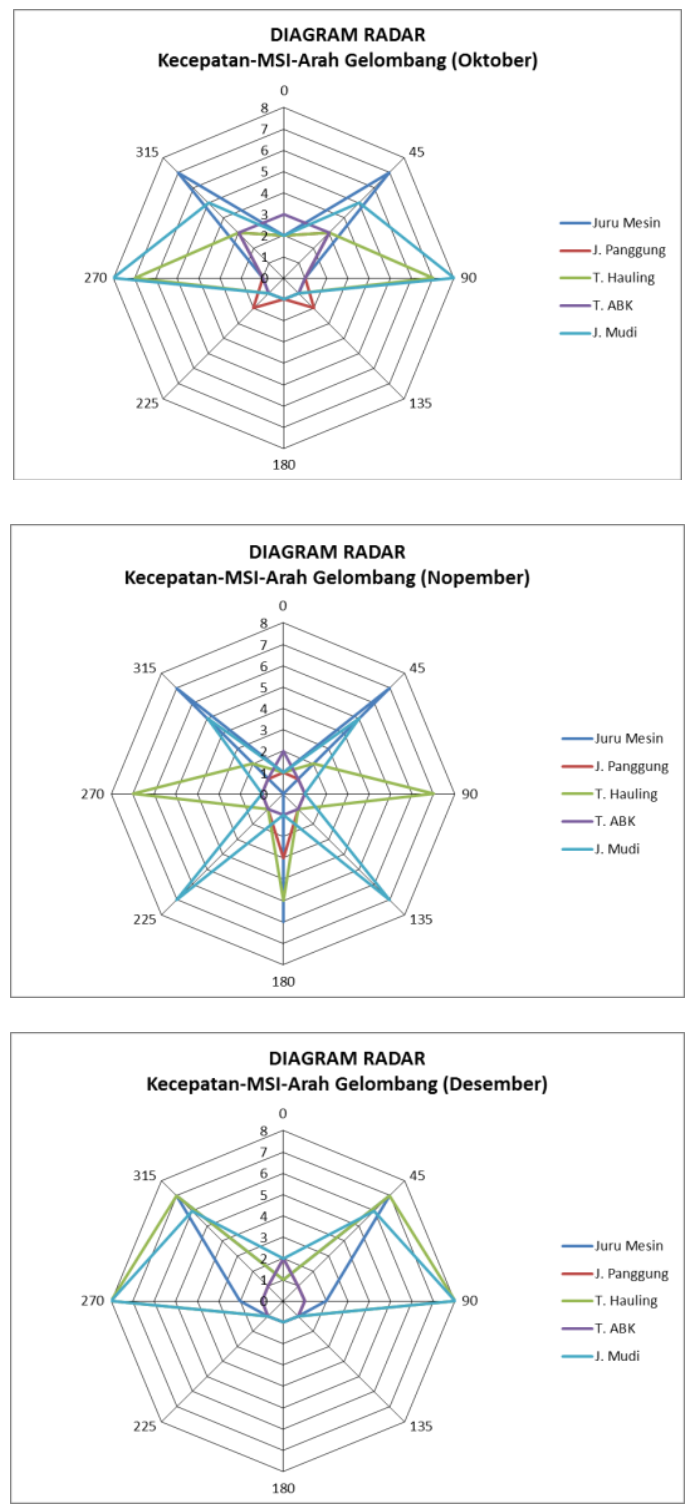

Gambar 7. Diagram Radar Kecepatan Bulan Oktober Desember

(Speed Polar Plot for October to December)

Untuk mengetahui hubungan tingkat keamanan/ kenyamanan $\mathrm{ABK}$ terhadap hasil tangkapan, dilakukan analisa korelasi antara indek operabilitas bulanan ABK pada setiap posisi diatas kapal yang ditinjau terhadap indek musim ikan maupun standar CPUE 2008-2009. 


\section{HASIL DAN PEMBAHASAN}

Berdasarkan diagram radar kecepatan bulanan untuk setiap lokasi diatas kapal yang ditinjau, didapatkan indek operabilitas bulanan dari lokasilokasi tersebut seperti terlihat pada gambar 8 .

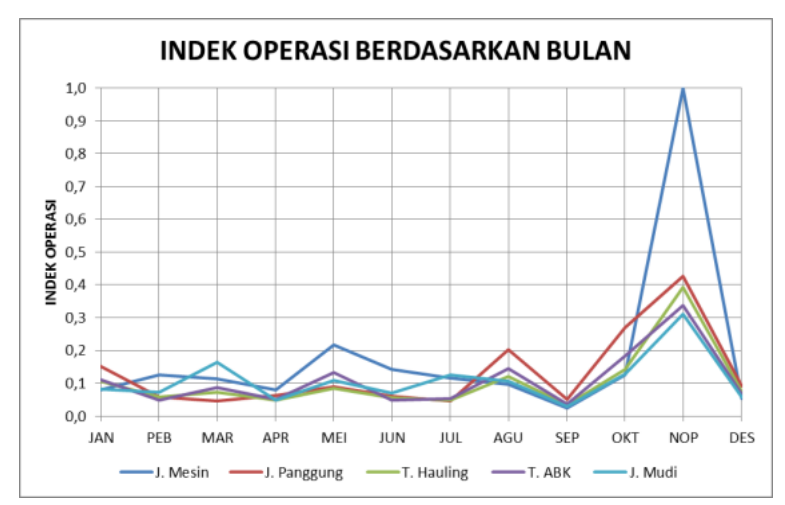

Gambar 8. Indek Operasi Bulanan Juru Mesin, Juragan Panggung, ABK, Juru Mudi dan Penarik Jaring

(Monthly Operational Indices of Engine

Master. Juragan Panggung, Crew, Quarter Master and Net Haulers)

Berdasarkan hasil analisa korelasi antara indek operabilitas sepanjang tahun dari setiap lokasi diatas kapal yang ditinjau terhadap indek musim ikan dan standar CPUE 2008-2009, diperoleh koefisien korelasi seperti terlihat pada Tabel 2.

Tabel 2. Korelasi indek operabilitas terhadap CPUE 2008-2009 dan Indek Musim Ikan.

(The Corellation among Operability Indices, CPUE 2008-2009 and Fishing Season Index)

\begin{tabular}{llcc}
\hline \multirow{2}{*}{ NO } & \multirow{2}{*}{ LOKASI } & \multicolumn{2}{c}{ KOEF. KORELASI } \\
\cline { 3 - 4 } & & $\begin{array}{c}\text { CPUE } \\
\mathbf{2 0 0 8 - 9}\end{array}$ & $\begin{array}{c}\text { MI } \\
(\mathbf{1 9 9 3 - 2 0 0 2})\end{array}$ \\
\hline 1 & J. Mesin & 0,8349 & 0,4621 \\
2 & J. Panggung & 0,8569 & 0,7728 \\
3 & P. Jaring & 0,8971 & 0,6406 \\
4 & T. ABK & 0,9239 & 0,6855 \\
5 & J. Mudi & 0,7598 & 0,4186 \\
\hline
\end{tabular}

Secara umum dapat dikatakan terdapat hubungan yang lebih baik antara indek operabilitas dengan CPUE 2008-2009 dari pada dengan indek musim ikan. Hal ini dicerminkan dengan besaran koefisien korelasi antara indek operabilitas dengan CPUE 2008-2009 sebesar 0,76-0,92. Sedangkan variasi koefisien korelasi sebesar 0,41 - 0,77 didapatkan untuk hubungan antara indek operabilitas dengan indek musim ikan.
Variasi koefisien korelasi yang rendah $(0,41$ 0,77 ) antara indek operabilitas dan indek musim ikan dapat disebabkan karena adanya ketidak kesesuaian kurun waktu antara data gelombang (2008-2009) yang digunakan dalam simulasi gerak kapal dan data yang digunakan dalam analisa indek musim ikan (1993-2002). Selain itu, indek musim ikan yang menggunakan data hasil tangkapan dalam kurun waktu 1993-2002 tersebut mendapatkan bahwa musim ikan 1995, 1996, 1998, 1999, dan 2000 tidak mengikuti pola musim ikan yang diperoleh (Merta dan Nurhakim. 2004). Hal lain, musim ikan yang diperoleh didasarkan pada total hasil tangkapan bulanan tanpa memperhatikan jumlah kapal yang menangkap (Wudianto. 2001) menyebutkan bahwa musim ikan lebih tepat digambarkan dengan fluktuasi bulanan CPUE.

Sebaliknya, koefisien korelasi yang tinggi $(0,76-$ 0,92 ) hampir untuk semua lokasi yang ditinjau antara indek operabilitas dan CPUE 2008-2009 dapat terjadi karena adanya kesesuaian kurun waktu antara data gelombang, hasil tangkapan dan jumlah kapal yang melakukan penangkapan.

Membandingkan spektrum gelombang bulanan (Gambar 5) dan indek operability bulanan (Gambar 8), terlihat tidak selalu memiliki hubungan. Secara umum luas spektrum gelombang menggambarkan besar energi gelombang. Berdasarkan hukum kekekalan energi, energi gelombang tersebut akan berubah menjadi energi gerak kapal pada 6 derajat kebebasan yang dapat digambarkan dalam bentuk spektrum gerak kapal. Secara mathematis hubungan tersebut adalah :

$$
S_{z}(\omega)=\left|R A O_{z}(\omega)\right|^{2} \cdot S_{w}(\omega)
$$

dimana $S_{z}(\omega)$ dan $S_{w}(\omega)$ adalah spektrum gerak vertikal kapal dan spektrum gelombang; $R A O_{z}(\omega)$ adalah Response Amplitude Operator gerak vertikal kapal dan $\omega$ adalah frekwensi gerak atau gelombang (Tello Ruiz et.al). $R A O_{z}(\omega)$ dikenal sebagai karakteristik spesifik gerak yang dicirikan dengan adanya frekwensi alamiah (natural). Frekwensi alamiah adalah frekwensi dimana jika terjadi gangguan dengan frekwensi tersebut; maka kapal akan bergerak dengan besaran tidak terbatas. Berdasarkan alasan tersebut, maka besaran percepatan gerak vertikal, sebagai dasar perhitungan $M S I$, tidak hanya tergantung dengan 
luas spektrum gelombang; tetapi juga tergantung dengan frekwensi puncak spektrum gelombang (wave peak frequency) dan frekwensi alamiah gerak vertikal kapal. Dimana frekwensi alamiah gerak kapal dipengaruhi oleh distribusi berat konstruksi, logistik dan muatan kapal.

Indek operabilitas untuk semua lokasi bekerja yang ditinjau pada bulan Nopember tertinggi dibandingkan pada bulan-bulan yang lain; hal ini berarti bahwa pada bulan tersebut keamanan dan kenyaman bekerja diatas kapal adalah maksimum. Sedangkan kondisi keamanan dan kenyaman terburuk terjadi ketika indek operabilitas minimum yang terjadi pada bulan September. Hal tersebut disebabkan frekuensi puncak gelombang bulan September $(0,19 \mathrm{~Hz})$ lebih mendekati frekuensi alamiah gerak vertikal kapal yang terjadi pada kisaran 0,65-0,72 Hz. Sedangkan frekuensi puncak gelombang bulan November $(0,14 \mathrm{~Hz})$ jaraknya lebih jauh dari frekuensi alamiah gerak vertikal kapal. Seperti terlihat pada Gambar 4 bahwa hal tersebut sesuai pula dengan puncak tertinggi dan terendah CPUE. Hal ini berarti ketika keamanan dan kenyamanan bekerja diatas kapal sangat kondusif maka hasil tangkapan akan maksimal; demikian juga sebaliknya.

Studi tentang pengaruh posisi diatas kapal terhadap body balance pada posisi berdiri dengan menggunakan parameter Motion Induced Interruptions (MII) mendapatkan bahwa posisi sebagai juragan panggung adalah pekerjaan yang paling berbahaya disusul penarik jaring dan juru mudi (Suryanto. 2012). Namun pada kenyataan dilapangan, juragan panggung pada saat bekerja selalu dalam posisi duduk; sehingga kondisi bekerja yang paling berbahaya adalah penarik jaring. Pada Tabel 2 terlihat bahwa koefisien korelasi tempat ABK terhadap CPUE adalah terbesar yang diikuti dengan koefisien korelasi penarik jaring. Namun pada kondisi riil, pada saat kapal menuju fishing ground, ABK yang tidak bertugas mengoperasikan kapal berkumpul ditempat $\mathrm{ABK}$ untuk beristirahat di bagian depan geladak utama. Pada saat sampai di fishing ground, ABK tersebut akan bertugas menebar dan menarik jaring ditempat yang telah ditentukan. Sehingga terdapat hubungan yang erat antara tingkat bahaya (MII), keamanan/ kenyamanan kerja (MSI) dan hasil tangkapan (CPUE).

Seperti disebutkan dalam bagian metode diatas bahwa indek operabilitas yang dihitung dalam studi ini hanya menggunakan parameter motion sickness incidences (MSI). Parameter yang dikembangkan oleh O'Hanlon dan Mc Cauley (1973) mencerminkan hubungan antara jumlah orang yang muntah terhadap frekwensi dan percepatan gerak vertikal. Selanjutnya teori ini dikembangkan dengan penggabungan variabel gerak anggukan, oleng dan lama terhadap gangguan gerakan (Mc Cauley et al. 1976) dimana selanjutnya oleh International Standartization Organization (ISO) dikembangkan petunjuk pengukuran MSI yang dikenal dengan ISO 2631-1. (ISO. 1997). Parameter lain hasil pengembangan MSI adalah Vomiting Incidence (VI); dimana perbedaan keduanya adalah pada teknik perhitungan (Lawther dan Griffin. 1987).

Riola dan Arboleya (2006) menyatakan bahwa terdapat 5 parameter untuk mengetahui pengaruh gerak kapal terhadap kinerja ABK. Parameter tersebut adalah; (1) Motion Indiced Interruptions (MII), (2) Motion Induced Fatique, (3) Cognitive Performance, (4) Motion Sickness Incidence (MSI), dan (5) Kebiasaan (Habituation). Namun dia juga menyebutkan bahwa parameter yang sangat berguna untuk keperluan tersebut adalah MII dan MSI

Sementara Colwell (1989) menyarankan penggunaan empat parameter untuk mengukur kinerja seseorang yang bekerja ditempat yang bergerak. Aspek tersebut adalah motion sickness incidence (MSI); motion-induced interruptions (MII); motion-induced fatigue (MIF); dan whole body vibration. Dimana keempat aspek tersebut juga harus memperhatikan lama gangguan gerak yang dialami dan jenis pekerjaan yang harus dilakukan.

Baitis (1995) memperkuat 2 pendapat diatas dengan menyatakan bahwa kinerja seseorang dipengaruhi oleh sistem biomekaniknya. Dimana sistem tersebut dapat diukur dengan menggunakan parameter kehilangan keseimbangan yang disebut Motion Induced Interruptions (MII). Parameter tersebut dapat memperkirakan kapan kondisi gerak kapal dapat mulai mengganggu seseorang untuk melakukan tugas tertentu pada posisi berdiri.

Stevens dan Parsons (2002) dalam studinya menunjukan pentingnya penggunaan parameter Motion Induced Fatigue (MIF) dalam mengkaji kinerja orang yang bekerja ditempat yang bergerak. Ia menemukan bahwa seseorang yang 
bekerja pada tempat yang bergerak mengalami sedikit pertambahan konsumsi oksigen; namun kapasitas maksimum organ tubuhnya untuk mengkonsumsi oksigen akan menurun sehingga dapat menyebabkan kelelahan Motion Induced Fatigue (MIF) dan akan berdampak pada menurunnya kinerja kognitifnya.

Sementara itu, Sarioz. $K$ dan Narli. E. (2005) dalam studinya menunjukan bahwa pemilihan parameter seakeeping dan batasannya yang dipilih mempengaruhi indek operabilitas kapal. Berdasarkan penjelasan diatas dapat dikatakan bahwa studi kinerja ABK diatas kapal hendaknya meliputi MII, MSI dan MIF. Penggunaan parameter-parameter tersebut dan pemilihan kriteria yang dipakai dapat menghasilkan indek operabilitas kapal yang lain dari yang diperoleh studi ini. (Sarioz. $K$ dan Narli. E. 2005) menambahkan bahwa indek operabilitas kapal sangat tergantung pula dengan pemilihan kriteria/ batasan yang dipakai.

Untuk meningkatkan keamanan dan kenyamanan kerja nelayan diatas kapal, perbaikan dapat dilakukan melalui 3 tahap. (1) Tahap perencanaan, melalui pemilihan perbandingan panjang kapal terhadap displacement, panjang terhadap lebar kapal, panjang terhadap sarat kapal dan panjang terhadap kecepatan kapal (Froud Number) yang sesuai. Dimana hal ini dapat memperkecil percepatan gerak vertikal kapal (Sayli et al. 2007). (2) Tahap operasional, melalui pengaturan kecepatan kapal dan mengarahkan kapal relatif terhadap gelombang secara tetap (Akinturk. 1997). (3) Tahap modifikasi, melalui pemasangan sayap bilga. Dimana hal juga dapat meningkatkan efisiensi pemakaian bahan bakar (Platonov $V G$ dan Trub MS. 2010).

\section{KESIMPULAN DAN SARAN}

Secara umum dapat disimpulkan bahwa (1) Terdapat hubungan yang erat antara indek operabilitas ABK terhadap catch per unit effort (CPUE). Hal ini ditunjukan dengan koefisien korelasi sebesar $(0,76$ - 0,92). (2) ABK kapal pukat cincin yang beroperasi di Selat Bali bekerja dalam kondisi keamanan dan kenyamanan kerja sesuai dengan kriteria ISO 2631-1. (3) Diantara posisi ABK yang ditinjau, kenyamanan dan keamanan kerja penarik jaring memiliki korelasi tertinggi $(0,897)$ terhadap hasil tangkapan.

Disarankan dilakukan studi serupa dengan menggunakan parameter MSI, MII dan MIF seperti disarankan oleh Colwell (1989), Baitis (1995) dan Riola (2006).

\section{DAFTAR PUSTAKA}

Akinturk, A. 1997. Inclusion of A Crew Safety Node Into The Preleminary Design of Fishing Vessels. Thesis in Partial Fulfiliment of the Requirement for the Degree of Doctor of Philosophy. Department of Mechanical Engineering. University of British Columbia.

Akinturk, A, Bass, D.W, Mac Kinnon, S, Vera, J dan Cumming, D. 2007. Habitability Considerations Onboard Fishing Vessels of the Newfoundland Fleet. National Research Council Canada. Publications Archive (NPArC). Canada: 1-7

Baitis, A.E, Holcombe, F.D, Conwell, S.L, Crossland, P, Colwell, J dan Pattison, J.H. 1995. Motion Induced Interruptions (MII) and Motion Induced Fatigue (MIF) experiments at the Naval Biodynamics Laboratory. Technical Report CRDKNSWC-HD-1423-01. Bethesda, MD. Naval Surface Warfare Center. Carderock Division.

Cauley, Mc.M.E, Jackson, W.R, Wylie, C.D, O'Hanlon, J.F dan Mackie R.R. 1976. Motion Sickness Incidence: Explolatory Studies of Habituation, Pitch and Roll and The Refinement of A Mathematical Model. Technical Report 1733-2. Human Factor Research Incoporated. Santa Barbara Research Park. Goleta. California.

Colwell, J.L. 1989. Human Factors in The Naval Environment : A Review of Motion Sickness and Biodynamic Problems. DREA Technical Memorandum 89/220. Dartmouth. Nova Scotia.

Dennis, St.M and Pierson, W.J. 1953. On the Motion Ships in Confused Seas. Transactions of the Society Naval Architects Marine Engineers (SNAME). Vol. 61. 280-354.

Dinas Kelautan dan Perikanan Prov. Jawa Timur. 2000. Fish Code Management. Papers Presented at The Workshop on The Fishery and Management of Bali Sardinella 
(Sardinella lemuru) in Bali Strait. FAO Rome.

FAO/ILO/IMO. 2005. Voluntary Guidelines. Design, Construction and Equipment for Small Fishing Vessels.

FAO. 2010. Safety at Sea for Small Scale Fisheries in Developing Countries. Safety for Fishermen : The Way Forward. GCP/GLO/200/MUL. September.

Griffin, M. J. 1990. Motion sickness. Handbook of Human Vibration. Academic Press. New York.

Grigoropoulosa, G.J. 2010. On Seakeeping Operability of Naval Ships. Nausivios Chora. Paper ID: NCH-2010-C8. Hellenic Naval Academy.

ISO 2631-1. 1997. Mechanical vibration and shock - Evaluation of human exposure to wholebody vibration - Part 1. General Requirements. International Organization for Standardization.

Lawther, A. and M.J, Griffin. 1987. Prediction of the incidence of motion sickness from the magnitude, frequency and duration of vertical oscillation. Journal of the acoustical society of America. 82 (3): 957-966

Lincoln, J.M dan Lucas, D.L. Commercial Fishing Fatalities, 2000-2009 : High-Risk Fisheries and Regional Trends. Pape presented at 4th International Fishing Industry Safety and Health Conference. Reykjavik, Iceland. 2009.

Merta, I. G.S dan Subhat, N. 2004. Musim Penangkapan Ikan Lemuru, Sardinella lemuru, Blekker 1853 di Perairan Selat Bali. Jurnal Penelitian Perikanan Indonesia. Edisi Sumber Daya dan Penangkapan Vol.10 No.6 Tahun 2004: 75-83

Merta, I.G.S.; Widana, K; Yunizal dan Basuki, R. 2000. Fish Code Management. Papers Presented at The Workshop on The Fishery and Management of Bali Sardinella (Sardinella lemuru) in Bali Strait. Status of The Lemuru Fishery in Bali Strait Its Development and Prospect. FAO Rome.

O'Hanlon, J.F dan Mc. Cauley, M.E. 1973. Motion Sickness Incidence as A Function of The Frequency and Acceleration of Vertical Sinusoidal Motion. National Technical Information Service. U. S. Department of Commerce. Springfield.

Platonov, V.G dan Trub, M.S (2010). Improvement of Seakeeping Qualities of Small Fishing Vessels as One of The Ways to
Increase Their Efficiency Energy. First International Symposium on Fishing Vessel Energy Efficiency E-Fishing. Vigo. Spain. May. 1-7

Prasetyo, A.P dan M, Natsir. 2011. Prosiding Seminar Hasil Penelitian Terbaik. 2010. Pengaruh Variabilitas Iklim Ekstrim Terhadap Perikanan Lemuru di Selat Bali. Jakarta. Balitbang Kelautan dan Perikanan - KKP: 2138

Riola, J.M dan Garcia, M. Arboleya. 2006. Habitability and Personal Space in Seakeeping Behaviour. Journal of Maritime Research. Vol. III. No.1. 41-54.

Sarioz, K dan Narli, E. 2005. Effect of Criteria on Seakeeping Performance Assessment. Ocean Engineering. No. 32: 1161-1171

Sayli, A, Alkan, A.D, Nabergoj, R dan Uysal, A.O. 2007. Seakeeping Assessment of Fishing Vessels in Conceptual Design Stage. Ocean Engineering. Vol 34. 724-738.

Stevens, S.C. dan Parsons, M.G. 2002. Effects of motion at sea on crew performance: A Survey. Marine Technology and SNAME News. Vol. 39. No.1: 29-47.

Suryanto; Manurung, D dan Candra, H. 2005. Laporan Teknis. Pengembangan Desain Kapal Tradisional Pantai Selatan Jawa Bali. Badan Riset Kelautan dan Perikanan. Pusat Riset Teknologi Kelautan.

Suryanto. 2012. Pengaruh Tinggi Geladak Terhadap Keselamatan Anak Buah kapal Pukat Cincin Yang beroperasi di Selat Bali. Jurnal Kelautan Nasional. Vol. 7. No.2. 109119.

Suryanto. 2012. Kajian Standarisasi Pengukuran Tonase Kapal Pukat Cincin di selat Bali dan Dampaknya Pada Pungutan Hasil Perikanan. Prosiding Seminar Nasional Perikanan Indonesia. Pusat Penelitian dan Pengebdian Masyarakat. Sekolah Tinggi Perikanan. Jakarta. Badan Pengembangan Sumber Daya Manusia Kelautan dan Perikanan. Kementerian Kelautan dan Perikanan. Jilid. 1: 153-162.

Stevens, S.C dan Parsons, M.G. 2002. Effects of Motion at Sea on Crew Performance : A Survey. Marine Technology. Vol. 39. No.1. 29-47.

Tello Ruiz, M, Ribeiro e Silva, S, Guedes Soares, C. Fishing Vessels Responses in Waves under Operational Conditions. Centre for Marine Technology and Engineering (CENTEC). 
Technical University of Lisbon, Instituto Superior Técnico. Portugal. http://www.ipen.org.br/downloads/XXI/186_ Tello_Ruiz_Manases.pdf. Diakses pada tanggal 22 Januari 2013.

Tupper, C.N. 1985. Fishing and Ship Motion Design Considerations Based on Observations of Operations. Proceeding of International Conference on Design, Construction and Operations of Commercial Fishing Vessel. Florida.

Wang, J, Pillar, A, Kwon, Y.S, Wall, A.D dan Loughran Rodríguez, C.G. 2005. An Analysis of Fishing Vessel Accidents. Accident Analysis and Prevention. No. 37. 1019-1024.

Wiyono, B. 2011. Model Dinamis Perikanan Lemuru (Sardinella Lemuru) di Selat Bali.
Thesis. Sekolah Pasca Sarjana. Institut Pertanian Bogor.

Wudianto. 2001. Analisis Sebaran dan Kelimpahan Ikan Lemuru (Sardinella lemuru Bleeker 1853) di Perairan Selat Bali: Kaitannya dengan Optimasi Penangkapan. Desertasi. Program Pasca Sarjana, IPB, Bogor.

Wudianto. 2011. Dinamika Perikanan Lemuru di Perairan Selat Bali. Paper presented at Seminar Perikanan Pelagis Kecil di Indonesia. Agustus. Jakarta

Yaakob, O dan Chau, Q.P. 2005. Weather Downtime and Its Effect on Fishing Operation in Peninsular Malaysia. Jurnal Teknologi, 42(A) Jun. Universiti Teknologi Malaysia. 13-26. 